\title{
Teknologi Informasi Memoderasi Pengaruh Pengendalian Intern dan Kompetensi Sumber Daya Manusia Pada Kualitas Laporan Keuangan
}

\author{
I Nyoman Andi Susena ${ }^{1}$ \\ Fakultas Ekonomi dan Bisnis \\ Universitas Udayana, Indonesia \\ Email: inyomanandisusena@gmail.com
}

\author{
Ni Luh Supadmi² \\ Fakultas Ekonomi dan Bisnis \\ Universitas Udayana, Indonesia
}

\begin{abstract}
ABSTRAK
Penelitian ini bertujuan untuk mengetahui apakah teknologi informasi memoderasi pengaruh pengendalian intern dan kompetensi sumber daya manusia pada kualitas laporan keuangan.Penelitian dilakukan pada organisasi perangkat daerah di kabupaten Badung sebanyak 28 organisasi perangkat daerah. Jumlah sampel yang diambil sebanyak 112 orang.Teknik analisis data yang digunakan adalah Moderated Regression Analysis (MRA). Hasil pengujian menunjukkan pengendalian intern berpengaruh positif dan signifikan pada kualitas laporan keuangan, kompetensi sumber daya manusia tidak berpengaruh pada kualitas laporan keuangan, teknologi informasi memperkuat pengaruh pengendalian intern dan kompetensi sumber daya manusia pada kualitas laporan keuangan.
\end{abstract}

Kata Kunci: SPI; Kompetensi; Laporan Keuangan; TI.

\section{Information Technology Moderate The Effect of Internal Control and Human Resource Competence on The Financial Statement Quality}

\begin{abstract}
The purpose of this research is to identify whether information technology moderate the impact of internal control and human resources competency in the financial statement quality. The Reseach was done to 28 regional government officials of Badung. The number of samples are 112 peoples. The technique that was used for the analysis is Moderated Regression Anlysis(MRA). The result of the test shows that internal control affects positively and significantly in the financial statement quality. Human resource competence does not affect the financial statement quality. Information technology strengthen the impact of internal control on financial statement qualityand information technology strengthen the impact of human reources competence on the financial statement quality.
\end{abstract}

Keywords: $\quad$ Control; Competence; IT; Financial Statement.

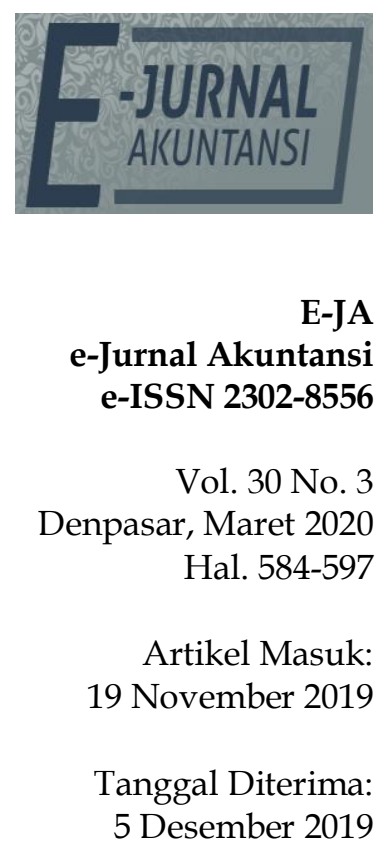

5 Desember 2019 


\section{PENDAHULUAN}

Fenomena yang menjadi sorotan utama pada organisasi sektor publik di Indonesia adalah adanya tuntutan dari masyarakat untuk meningkatkan akuntabilitas dan transparansi atas lembaga-lembaga publik baik di pusat maupun di daerah. Akuntabilitas dan transparansi keuangan negara adalah tujuan penting dari sektor publik (Tambingon, et al., 2018). Pemerintah berkewajiban menyusun dan menyajikan laporan keuangan sebagai salah satu bentuk pertanggungjawaban di dalam pengelolaan keuangan. Secara umum, pelaporan keuangan harus memberikan informasi yang diperlukan untuk evaluasi situasi keuangan, konstitusi ekonomi lembaga, evaluasi kinerja, kemampuan profitabilitas, evaluasi kondisi pengamanan keuangan, penggunaan arus kas, evaluasi situasi tanggung jawab manajemen, kinerja tugas hukum, penyediaan informasi pelengkap untuk memahami informasi yang dilaporkan, informasi keuangan yang lebih baik dan usulan situasi di masa depan (Golshani, 2017). Berdasarkan PP No. 71 Tahun 2010 tentang Standar Akuntansi Pemerintahan (SAP) menjelaskan karakteristik laporan keuangan yang berkualitas yaitu; relevan, andal, dapat dibandingkan, dan dapat dipahami.

Kewo dan Afiah (2017) mendefinisikan kualitas laporan keuangan sebagaimana dilaporkan sesuai dengan standar akuntansi pelaporan keuangan yang menunjukkan posisi keuangan dan hasil operasi suatu entitas pada akhir periode. Untuk menilai kualitas laporan keuangan pemerintah pusat maupun daerah perlu dilakukan audit dan pemeriksaan oleh badan atau instansi yang berwenang. Badan Pemeriksa Keuangan Republik Indonesia (BPK RI) merupakan badan yang bertugas untuk melakukan audit atas laporan keuangan pemerintah daerah setiap tahunnya dan mengeluarkan opini atas hasil audit tersebut.

Berdasarkan hasil audit yang dilakukan oleh BPK pada laporan keuangan pemerintah daerah di wilayah provinsi Bali, BPK masih menemukan beberapa permasalahan dan penyimpangan dalam proses penyusunan laporan keuangan yaitu seperti masih ditemukannya beberapa kelemahan sistem pengendalian intern dalam penyusunan laporan keuangan dan ketidakpatuhan terhadap peraturan perundang-undangan (bali.antaranews.com, 2019). Permasalahan ini diduga diakibatkan oleh kurang efektifnya penerapan pengendalian intern dan rendahnya kompetensi SDM yaitu pemahaman terhadap peraturan perundangundangan yang berlaku.

Kabupaten Badung memperoleh opini WTP dari BPK yang didasarkan pada ikhtisar hasil pemeriksaan BPK tahun 2018 untuk LKPD tahun 2017.Namun, meskipun opini yang diberikan BPK kepada LKPD kabupaten Badung berupa opini WTP tetapi berdasarkan dari Laporan Hasil Pengawasan (LHP) semester II perwakilan Badan Pengawasan Keuangan dan Pembangunan (BPKP) provinsi Bali yang terbit pada tahun 2018, BPKP provinsi Bali yang melakukan bimbingan konsultasi review atas laporan keuangan pemerintah daerah berbasis akrual sesuai dengan surat Menteri Dalam Negeri Nomor 900/795/B3/IJ tanggal 31 Agustus 2016 dan surat edaran deputi kepala BPKP bidang pengawasan penyelenggaraan keuangan daerah nomor SE82/D4/03/2017 tanggal 3 Februari 2017, yang dilakukan di kabupaten Badung, kabupaten Klungkung dan kabupaten Buleleng. Adapun permasalahan umum 
yang ditemukan di tiga pemerintah daerah tersebutadalah: Pengelola keuangan daerah belum sepenuhnya paham terhadap mekanisme pencatatan transaksi keuangan secara umum untuk mewujudkan fungsi akuntansi sejak analisis transaksi sampai dengan pelaporan keuangan. OPD belum menyusun laporan keuangan yang terdiri dari neraca, Laporan Realisasi Anggaran (LRA), Laporan Operasional (LO), Laporan Perubahan Ekuitas (LPE), dan Catatan atas Laporan Keuangan (CaLK) secara mandiri, sehingga laporan keuangan konsolidasi belum didukung dengan laporan keuangan OPD. Penghitungan beban penyusutan dan akumulasi penyusutan belum selesai seluruhnya dan masih terdapat selisih antara perhitungan pendapatan dan belanja yang bersumber dari dana BOS antara dinas pendidikan pemuda dan olahraga dengan bagian keuangan. Keterlambatan penyelesaian penyusunan LKPD Kabupaten sehingga draft LKPD terlambat diserahkan kepada tim pelaksana review. Tim review inspektorat kabupaten belum sepenuhnya memahami dan mampu melakukan review laporan keuangan berbasis akrual dan sekaligus menyusun laporan hasil review sesuai dengan ketentuan yang berlaku.

Temuan-temuan yang diperoleh dari LHP semester II tahun 2018 yang diterbitkan oleh perwakilan BPKP provinsi Bali diatas mendukung temuan dari perwakilan BPK provinsi Bali yang menyatakan bahwa dalam proses penyusunan laporan keuangan masih ditemukan beberapa kelemahan dalam pengendalian intern dan ketidakpatuhan terhadap peraturan perundangundangan. Selain temuan permasalahan pada proses penyusunan LKPD, temuan lain yang didapat perwakilan BPKP Provinsi Bali yaitu perwakilan BPKP provinsi Bali melakukan Penghitungan Kerugian Keuangan Negara (PKKN) yang dilakukan atas permintaan dari Aparat Penegak Hukum (APH) dalam rangka membantu penyidikan. Tahun 2017 telah diterbitkan 9 (sembilan) laporan hasil Penghitungan Kerugian Keuangan Negara (PKKN) dengan nilai Rp. 13.765.825.144 disajikan pada Tabel 1.

\section{Tabel 1. Hasil Penghitungan Kerugian Keuangan Negara}

\begin{tabular}{llll}
\hline No & $\begin{array}{l}\text { Lokasi Kasus } \\
\text { (Pemda) }\end{array}$ & $\begin{array}{l}\text { Jumlah } \\
\text { kasus }\end{array}$ & $\begin{array}{l}\text { Nilai Kerugian } \\
(\mathrm{Rp})\end{array}$ \\
\hline 1 & Kota Denpasar & 1 & $2.853 .766 .355,00$ \\
2 & Kabupaten Tabanan & 1 & $200.000 .000,00$ \\
3 & Kabupaten Bangli & 1 & $134.414 .000,00$ \\
4 & Kabupaten Klungkung & 1 & $94.344 .494,78$ \\
5 & Kabupaten Jembrana & 3 & $1.065 .800 .000,00$ \\
6 & Kabupaten Badung & 1 & $952.200 .000,00$ \\
7 & Provinsi Bali & 1 & $8.465 .300 .294,00$ \\
& Jumlah & 9 & $13.765 .825 .144,00$ \\
\hline
\end{tabular}

Sumber: http://bpkp.go.id

Berdasarkan hasil Penghitungan Kerugian Keuangan Negara (PKKN), nilai kerugian negara atas kasus dugaan tindak pidana korupsi yang material di kabupaten badung sebesar Rp 952.200.000,00. Hasil Penghitungan Kerugian Keuangan Negara (PKKN) atas kasus dugaan tindak pidana korupsi yang material adalah berupa pengambilalihan aset negara dengan pensertifikatan tanah, penyelewengan pengadaan barang dan jasa, penerimaan daerah yang tidak disetor dan digunakan langsung untuk keperluan pribadi serta bantuan 
sosial dan hibah dari pemerintah. Kerugian atas kasus dugaan tindak pidana korupsi ini mengindikasikan bahwa masih kurang efektifnya pengendalian intern di pusat pemerintahan kabupaten Badung sehingga masih ada celah terjadinya penyelewengan dan penyimpangan dalam pengelolaan keuangan. Meskipun nilai kerugian atas kasus dugaan tindak pidana korupsi yg terjadi di kabupaten Badung lebih rendah dari provinsi Bali, kota Denpasar dan kabupaten Jembrana, namun apabila dibiarkan tentunya akan memberikan dampak yang lebih buruk kedepannya pada kualitas LKPD kabupaten Badung. Kabupaten Badung merupakan kabupaten dengan tingkat Pendapatan Asli Daerah (PAD) tertinggi di provinsi bali sehingga pertanggungjawaban atas pengelolaan keuangan menjadi sangat kompleks. Oleh karena itu, permasalahanpermasalahan dan penyimpangan yang terjadi harus segera diantisipasi dan diselesaikan.

Kabupaten Badung dituntut untuk memiliki sistem pengendalian yang kuat agar tidak terjadi kesalahan maupun penyelewengan dalam proses penyusunan laporan keuangan dan dalam pengelolaan keuangan daerah. Efektivitas sistem pengendalian intern sangat penting untuk mencegah terjadinya tindakan penyelewengan danuntuk meningkatkan kualitas dari laporan keuangan. Sistem pengendalian internal yang efektif dipastikan oleh identifikasi dan evaluasi lingkungan kontrol yang merepresentasikan kesadaran kontrol keseluruhan dari suatu entitas (Rubino, et al., 2017). Dalam sektor publik, PP No. 60 Tahun 2008 tentang Sistem Pengendalian Intern Pemerintah (SPIP) merupakan pedoman bagi pemerintah pusat dan pemerintah daerah dalam melakukan perancangan pengendalian intern.

Efektivitas penerapan pengendalian intern diorganisasi khususnya pemerintah daerah sangat diperlukan agar laporan keuangan yang dihasilkan semakin berkualitas. Menurut Urbanik (2016)dengan memberlakukan pengendalian, unit pemerintah daerah dapat meningkatkan manajemen keuangan dan kinerjanya secara keseluruhan. Penelitian tentang pengaruh pengendalian intern pada kualitas LKPD sudah banyak dilakukan dan memperoleh hasil yang beragam. Penelitian yang dilakukan oleh Mahaputra \& Putra (2014), Nurillah (2014), Surastiani dan Handayani (2015),Sudiarianti et al. (2015), Anwar \& Mukadarul (2016), Andrianto (2017), Setiawan \& Gayatri (2017) danTrisnawati \& Wiratmaja (2018) memperoleh hasil pengendalian intern berpengaruh positif dan signifikan pada kualitas laporan keuangan. Soimah (2014) menyatakan bahwa sistem pengendalian intern pemerintah berpengaruh positif dan signifikan pada kualitas LKPD, serta Sari (2016) dan Manullang (2016) memperoleh hasil bahwa sistem pengendalian intern berpengaruh signifikan terhadap Kualitas LKPD. Namun hasil yang berbeda diperoleh oleh Karmila et al. (2014) dan Septarini \& Papilaya (2016) membuktikan secara empiris bahwa pengendalian intern yang termasuk di dalamnya pengendalian intern akuntansi tidak berpengaruh pada kualitas laporan keuangan.

Selain efektivitas dalam penerapan pengendalian intern, SDM yang terdapat di lingkungan pusat pemerintahan kabupaten Badung juga harus memiliki kompetensi yang memadai terutama dalam hal pemahaman terhadap Standar Akuntansi pemerintahan (SAP) agar tidak terjadi kesalahan analisis transaksi dalam proses penyusunan LKPD. SDM merupakan salah satu indikator 
yang dapat menentukan keberhasilan suatu organisasi. Nurillah (2014) menyatakan bahwa SDM yang paham dan kompeten dalam akuntansi keuangan pemerintahan daerah sangat dibutuhkan dalam menghasilkan laporan keuangan daerah yang berkualitas. Kompetensi SDM merupakan penentu utama keberhasilan organisasi dan karakteristik dasar seseorang untuk berpikir, berperilaku, bertindak dan menarik kesimpulan yang dapat dilakukan dan dipelihara oleh seseorang pada periode tertentu (Hidayah \& Zarkasyi, 2017). SDM yang berkompeten akan mampu menyelesaikan setiap pekerjaan dengan efektif dan efisien. Penelitian tentang pengaruh kompetensi SDM pada kualitas laporan keuangan sudah cukup banyak dilakukan dan memperoleh hasil yang beragam. Penelitian yang dilakukan olehIhsanti (2014), Kiranayanti dan Erawati (2016), Utama (2017) dan Agung (2018) mendapatkan hasil jika kompetensi SDM berpengaruh positif dan signifikan pada kualitas laporan keuangan. Diani (2014), Mahaputra \&Putra (2014), Nurillah (2014) dan Suarmika (2016) memperoleh hasil bahwa kapasitas SDM berpengaruh positif dan signifikan terhadap kualitas laporan keuangan. Manullang (2016) membuktikan bahwa SDM berpengaruh signifikan pada kualitas laporan keuangan. Hasil penelitian yang berbeda didapatkan oleh Ponamon (2014) dan Ningrum (2018) menyatakan bahwa kompetensi SDM tidak berpengaruh terhadap kualitas LKPD. Hasil yang sama diperoleh oleh Siwambudi (2017) yang memperoleh hasil kompetensi SDM tidak berpengaruh positif pada kualitas laporan keuangan SKPD kabupaten Klungkung. Sedangkan Karmila et al. (2014), Suwanda (2015) dan Rahmawati (2015) yang membuktikan secara empiris bahwa kapasitas sumber daya manusia tidak berpengaruh terhadap kualitas laporan keuangan.

Hasil penelitian sebelumnya menyatakan adanya inkonsistensi pengaruh pengendalian intern dan kompetensi SDM pada kualitas LKPD dimana salah satu penyebabnya adalah adanya faktor kontinjensi. Penelitian ini menduga adanya pemanfaatan teknologi informasi dapat berperan sebagai variabel pemoderasi. Semakin maju dan berkembangnya teknologi informasi akan memberikan dampak positif dalam proses penyusunan laporan keuangan dan pengelolaan kuangan pemerintah. Pemerintah daerah wajib menyusun laporan keuangan untuk mempertanggungjawabkan pengelolaan keuangan daerahnya. Laporan keuangan yang berkualitas dapat dihasilkan dengan mengaplikasikan suatu sistem yang dapat diandalkan dan membantu mendeteksi kesalahan dengan cepat didalam proses penyusunan laporan keuangan.

Sistem Informasi Manajemen Daerah (SIMDA) merupakan produk dari teknologi informasi yang dikembangkan oleh BPKP untuk digunakan oleh pemerintah daerah dalam mengelola keuangan secara komprehensif mulai dari sistem keuangan, aset daerah serta pendapatan daerah. SIMDA telah digunakan oleh banyak pemerintah daerah termasuk kabupaten Badung.Adanya pemanfaatan teknologi informasi berupa SIMDA diharapkan dapat membantu meningkatkan efektifitas dan efisiensi pemerintah daerah di dalam pengelolaan keuangan daerah khususnya di kabupaten Badung sehingga laporan keuangan yang dihasilkan akan semakin berkualitas. Hal ini didukung dengan penelitian Mahaputra \& Putra (2014) yang menyatakan bahwa pemanfaatan teknologi informasi berpengaruh positif dan signifikan terhadap kualitas informasi pelaporan keuangan pemerintah daerah. Primayana et al (2014) menyatakan 
bahwa pemanfaatan teknologi informasi berpengaruh positif dan signifikan terhadap keandalan pelaporan keuangan pemerintah desa. Sari et al (2014) menyatakan bahwa pemanfaatan sistem informasi akuntansi keuangan daerah berpengaruh signifikan terhadap kualitas laporan keuangan pemerintah daerah. Haza (2015) menyatakan bahwa pemanfaatan teknologi informasi berpengaruh positif dan signifikan pada kualitas laporan keuangan SKPD pemerintah kabupaten Padang \& Andrianto (2017) yang membuktikan bahwa teknologi informasi berpengaruh positif pada kualitas laporan keuangan.

Berdasarkan teori stewardship, pemerintah sebagai agen berkewajiban untuk memberikan pertanggungjawaban atas pengelolaan keuangan kepada rakyat sebagai prinsipal berupa laporan keuangan yang berkualitas. Salah satu faktor yang dapat mempengaruhi kualitas laporan keuangan adalah efektivitas penerapan pengendalian intern di pemerintahan. Sistem pengendalian intern merupakan cara untuk mengawasi kinerja dari SDM suatu entitas dan mencegah adanya penyimpangan maupun fraud.

Hal ini didukung oleh penelitian yang dilakukan olehTrisnawati dan Wiratmaja (2018), Soimah (2014), Sari (2016), Andrianto (2017), Mahaputra \& Putra (2014), Manullang (2016), Anwar \& Mukadarul (2016), Surastiani dan Handayani (2015), dan Sudiarianti et al (2015) yang membuktikan bahwa sistem pengendalian intern berpengaruh positif terhadap kualitas laporan keuangan pemerintah daerah dan penelitian Sugandi et al (2014) yang memperoleh hasil bahwa sistem pengendalian internal memiliki pengaruh signifikan positif terhadap keterandalan laporan keuangan pemerintah daerah. Berdasarkan uraian, teori dan hasil penelitian sebelumnya, maka hipotesis yang diajukan adalah:

$\mathrm{H}_{1}$ : Pengendalian intern berpengaruh positif pada kualitas laporan keuangan.

Berdasarkan teori stewardship, pemerintah sebagai agen berkewajiban untuk memberikan pertanggungjawaban atas pengelolaan keuangan kepada rakyat sebagai prinsipal berupa laporan keuangan yang berkualitas. Sumber daya manusia yang berkompeten dalam bidang akuntansi merupakan salah satu faktor yang dapat meningkatkan kualitas laporan keuangan. Sumber daya manusia dituntut untuk memiliki keahlian akuntansi yang cukup memadai agar meminimalisir terjadinya kekeliruan dan kesalahan dalam proses penyusunan laporan keuangan.

Hal ini didukung oleh penelitian yang dilakukan oleh Agung (2018), Kiranayanti dan Erawati (2016), Nurillah (2014), Mahaputra \& Putra (2014), Afiah \& Rahmatika (2014) dan Manullang (2016) yang membuktikan secara empiris bahwa kompetensi SDM berpengaruh signifikan positif pada kualitas LKPD. Berdasarkan teori, uraian dan hasil penelitian sebelumnya, maka hipotesis yang diajukan adalah:

$\mathrm{H}_{2}$ : Kompetensi SDM berpengaruh positif pada kualitas laporan keuangan.

Ketidakkonsistenan hasil penelitian terkait pengaruh SPIP pada kualitas LKPD diduga dipengaruhi oleh pemanfaatan teknologi informasi sebagai faktor kontinjensi yang dapat memperlemah atau memperkuat pengaruh pengendalian intern pada kualitas LKPD. Pemanfaatan teknologi informasi yang adamembuat pengendalian intern yang terdapat dalam organisasi akan semakin baik, karena pengendalian intern tersebut akan terintegrasi ke dalam satu sistem sehingga 
dapat memberikan kemudahan dalam memantau segala aktivitas di dalam organisasi dan lebih cepat dalam mendeteksi terjadinya penyimpangan dan fraud.Berdasarkan teori, uraian dan hasil penelitian sebelumnya, maka hipotesis yang diajukan adalah:

$\mathrm{H}_{3}$ : Teknologi informasi memperkuat pengaruh pengendalian intern pada kualitas laporan keuangan.

Hasil penelitian terdahulu terkait pengaruh kompetensi SDM pada kualitas LKPD terjadi ketidakkonsistenan hasil, hal ini diduga dipengaruhi oleh pemanfaatan teknologi informasi sebagai faktor kontinjensi yang mampu memperlemah atau memperkuat pengaruh kompetensi SDM pada kualitas LKPD. Pemanfaatan teknologi merupakan salah satu faktor yang dapat mempengaruhi kualitas LKPD yang dihasilkan oleh pemerintah daerah. Dalam rangka mewujudkan tujuan organisasi, termasuk tujuan untuk mewujudkan laporan keuangan yang berkualitas pemanfataan teknologi informasi sangat diperlukan untuk terciptanya efektivitas dan efisiensi kinerja dari SDM. Dalam penyusunan laporan keuangan, apabila sumber daya manusia yang berkompeten didukung dengan adanya pemanfaatan teknologi informasi yang tepat maka akan menciptakan kecepatan dan ketepatan dalam pemrosesan transaksi yang akan berdampak pada kualitas laporan keuangan yang dihasilkan. Dengan adanya teknologi informasi juga memberikan manfaat dalam meminimalisir terjadinya kesalahan, biaya pemrosesan yang lebih rendah, efektivitas dan efisiensi waktu dan dapat menyimpan data dalam kapasitas besar. Berdasarkan teori, uraian dan hasil penelitian sebelumnya, maka hipotesis yang diajukan adalah:

$\mathrm{H}_{4}$ : Teknologi informasi memperkuat pengaruh kompetensi SDMpada kualitas laporan keuangan.

\section{METODE PENELITIAN}

Variabel dalam penelitian ini adalah variabel terikat (dependent) yaitu Kualitas Laporan Keuangan, variabel bebas (independent) yaitu Pengendalian Intern, Kompetensi SDM dan variabel moderasi yaitu Teknologi Informasi. Penelitian ini dilakukan pada organisasi perangkat daerah di kabupaten Badung sebanyak 28 OPD. Jumlah sampel yang diambil sebanyak 112 orang. Pengambilan sampel dalam penelitian ini dilakukan secara nonprobabilitysampling, yaitu dengan menggunakan pendekatan purposive sampling. Purposive sampling yaitu penentuan sampel dengan menggunakan pertimbangan tertentu yang sesuai dengan kriteria yang ditentukan. Adapun kriteria pengambilan sampel dalam penelitian ini adalah: OPD di kabupaten Badung yang berbentuk dinas dan badan. Perangkat daerah yang menjabat sebagai kepala OPD, kepala sub bagian keuangan, bendahara OPD dan satu staf sub bagian keuangan yang bekerja pada masing-masing OPD yang berbentuk dinas dan badan. Metode pengumpulan data yang digunakan adalah metode survei berupa kuesioner. Teknik analisis data yang digunakan pada penelitian ini adalah Moderated Regression Analysis (MRA). 


\section{HASIL DAN PEMBAHASAN}

Statistik deskriptif dalam penelitian ini disajikan untuk memberikan informasi tentang karakteristik variabel penelitian, antara lain minimum, maksimum, mean, dan standar deviasi Hasil statistik deskriptif penelitian ini dapat dilihat pada Tabel 2.

\section{Tabel 2. Hasil Statistik Deskriptif}

\begin{tabular}{llllll}
\hline Variabel & $\mathrm{N}$ & Min & Maks & Mean & $\begin{array}{l}\text { Std. } \\
\text { Deviation }\end{array}$ \\
\hline $\begin{array}{l}\text { Pengendalian Intern }\left(\mathrm{X}_{1}\right) \\
\begin{array}{l}\text { Kompetensi Sumber Daya Manusia } \\
\left(\mathrm{X}_{2}\right)\end{array}\end{array}$ & 100 & 28,00 & 40,00 & 33,9100 & 3,46146 \\
Teknologi Informasi $\left(\mathrm{X}_{3}\right)$ & 100 & 16,00 & 44,00 & 35,4700 & 3,75904 \\
$\begin{array}{l}\text { Kualitas Laporan Keuangan }(\mathrm{Y}) \\
\text { Valid N (listwise) }\end{array}$ & 100 & 32,00 & 44,00 & 20,8400 & 2,37291 \\
& & & & & 4,16977
\end{tabular}

Sumber: Data Penelitian, 2019

Tabel 2. Menunjukkan hasil statistik deskriptif dari variabel-variabel yang diteliti, variabel pengendalian intern $\left(X_{1}\right)$ mempunyai nilai minimum dan maksimum sebesar 28,00 dan 40,00. Rata-rata sebesar 33,9100 dan standar deviasi sebesar 3,46146. Nilai rata-rata sebesar 33,9100 menunjukkan secara rata-rata jawaban responden mengarah ke nilai maksimum yang artinya pengendalian intern cukup efektif.Variabel kompetensi SDM $\left(\mathrm{X}_{2}\right)$ mempunyai nilai minimum dan maksimum sebesar 28,00 dan 44,00. Rata-rata sebesar 35,4700 dan standar deviasi sebesar 3,75904. Nilai rata-rata sebesar 35,4700 menunjukkan bahwa secara rata-rata jawaban responden mengarah ke nilai maksimum yang artinya kompetensi sumber daya manusia cukup tinggi.Variabel teknologi informasi $\left(X_{3}\right)$ mempunyai nilai minimum dan maksimum sebesar 16,00 dan 24,00 . Rata-rata sebesar 20,8400 dan standar deviasi sebesar 2,37291. Nilai rata-rata 20,8400 menunjukkan secara rata-rata jawaban responden mengarah ke nilai maksimum yang artinya tingkat pemanfataan teknologi informasi cukup tinggi. Variabel kualitas laporan keuangan $(Y)$ mempunyai nilai minimum dan maksimum sebesar 32,00 dan 44,00. Rata-rata sebesar 38,1300 dan standar deviasi sebesar 4,16977. Nilai rata-rata sebesar 38,1300 menunjukkan bahwa secara rata-rata jawaban responden mengarah ke nilai maksimum yang artinya kualitas laporan keuangan cukup tinggi.

Uji asumsi klasik pada penelitian ini yaitu uji normalitas, uji multikolinearitas dan uji heteroskedastisitas. Hasil uji asumsi klasik penelitian dapat dilihat pada Tabel 3.

Tabel 3. Rangkuman Hasil Uji Asumsi Klasik

\begin{tabular}{lllll}
\hline \multirow{2}{*}{$\begin{array}{l}\text { Uji } \\
\text { Normalitas }\end{array}$} & \multirow{2}{*}{ Variabel } & Uji & \multicolumn{2}{l}{$\begin{array}{l}\text { Uji } \\
\text { Multikoleniaritas }\end{array}$} \\
\cline { 4 - 5 } & & Heteroskedastisitas & Tolerance & VIF \\
\hline Signifikansi & Pengendalian Intern $\left(\mathrm{X}_{1}\right)$ & 0,062 & 0,580 & 1,723 \\
$=0,339$ & Kompetensi SDM $\left(\mathrm{X}_{2}\right)$ & 0,885 & 0,710 & 1,408 \\
& Teknologi Informasi $\left(\mathrm{X}_{3}\right)$ & 0,383 & 0,563 & 1,775 \\
& Interaksi $\mathrm{X}_{1}{ }^{*} \mathrm{X}_{3}$ & 0,110 & & \\
& Interaksi $\mathrm{X}_{2}{ }^{*} \mathrm{X}_{3}$ & 0,688 & & \\
\hline
\end{tabular}

Sumber: Data Penelitian, 2019 
Berdasarkan Tabel 3. diketahui bahwa hasil uji normalitas memiliki nilai signifikansi 0,339 > 0,05 yang menunjukkan bahwa data penelitian berdistribusi normal. Berdasarkan Tabel 3. diketahui bahwa tidak terjadi gejala multikolinearitas. Hal ini ditunjukkan dari nilai tolerence dan VIF dari setiap variabel bebaslebih besar dari 0,1 dan lebih kecil dari 10. Berdasarkan Tabel 3 diketahui bahwa tidak terjadi gejala heteroskedastisitas dalam model. Hal ini ditunjukkan dari nilai hetroskedastisitas setiap variabel dan interaksi yang semua nya lebih besar dari 0,05.

Moderated Regression Analysis (MRA) digunakan untuk memperoleh gambaran mengenai kemampuan teknologi informasi memoderasi pengaruh pengendalian intern dan kompetensi SDM pada kualitas laporan keuangan. Hasil Uji MRA dapat dilihat pada Tabel 4.

Tabel 4. Hasil Moderated Regression Analysis

\begin{tabular}{|c|c|c|c|c|c|}
\hline \multirow[t]{2}{*}{ Model } & \multicolumn{2}{|c|}{$\begin{array}{l}\text { Unstandardized } \\
\text { Coefficients }\end{array}$} & \multicolumn{3}{|c|}{$\begin{array}{l}\text { Standardized } \\
\text { Coefficients }\end{array}$} \\
\hline & $\mathrm{B}$ & Std.Error & Beta & $\mathrm{t}$ & Sig. \\
\hline (Constant) & 10,660 & 2,427 & & 4,329 & 0,000 \\
\hline Pengendalian Intern $\left(\mathrm{X}_{1}\right)$ & 0,321 & 0,081 & 0,267 & 3,964 & 0,000 \\
\hline Kompetensi SDM $\left(X_{2}\right)$ & 0,034 & 0,071 & 0,031 & 0,480 & 0,633 \\
\hline Teknologi Informasi $\left(\mathrm{X}_{3}\right.$ & 0,343 & 0,116 & 0,195 & 2,966 & 0,004 \\
\hline $\mathrm{X}_{1} \cdot \mathrm{X}_{3}$ & 0,274 & 0,111 & 0,254 & 2,470 & 0,015 \\
\hline$X_{2} \cdot X_{3}$ & 0,386 & 0,117 & 0,354 & 3,292 & 0,001 \\
\hline Adjusted $R_{\text {square }}$ & \multicolumn{2}{|c|}{0,764} & & & \\
\hline Fhitung & \multirow{2}{*}{\multicolumn{2}{|c|}{65,085}} & & & \\
\hline F Sig & & & & & \\
\hline
\end{tabular}

Sumber: Data Penelitian, 2019

Berdasarkan hasil analisis MRA pada Tabel 4. modelMRA yang terbentuk pada penelitian ini adalah sebagai berikut.

$Y=10,660+0,321 X_{1}+0,034 X_{2}+0,343 X_{3}+0,274 X_{1} \cdot X_{3}+0,386 X_{2} \cdot X_{3}+\varepsilon$

Nilai kostanta 10,660 menandakan bahwa pengendalian intern, kompetensi sumber daya manusia, interaksi teknologi informasi dengan pengendalian intern dan kompetensi sumber daya manusia adalah sama dengan nol, maka kualitas laporan keuangan meningkat sebesar 10,660.Nilai koefisien regresi pengendalian intern sebesar 0,321 menandakan jika pengendalian intern meningkat sebesar satu satuan, maka kualitas laporan keuangan akan meningkat sebesar 0,321 dengan asumsi variabel lainnya sama dengan nol.Nilai koefisien regresi kompetensi sumber daya manusia sebesar 0,034 memiliki artijika kompetensi meningkat sebesar satu satuan, maka kualitas laporan keuangan akan meningkat sebesar 0,034 dengan asumsi variabel lainnya sama dengan nol.Nilai koefisien regresi teknologi informasi sebesar 0,343 memiliki arti jika teknologi informasi meningkat sebesar satu satuan, maka kualitas laporan keuangan akan meningkat sebesar 0,343 dengan asumsi variabel lainnya sama dengan nol.Nilai koefisien moderasi antara pengendalian intern dengan teknologi informasi sebesar 0,27 memiliki arti setiap interaksi pengendalian intern dengan teknologi informasi meningkat satu satuan, maka kualitas laporan keuangan akan meningkat sebesar 0,274. Nilai koefisien moderasi antara kompetensi sumber daya manusia dengan teknologi informasi sebesar 0,386 
memiliki arti bahwa setiap interaksi kompetensi sumber daya manusia dengan teknologi informasi meningkat satu satuan, maka kualitas laporan keuangan akan meningkat sebesar 0,386.

Tabel 4. menunjukkan hasil uji kelayakan model (uji F).Nilai $\mathrm{F}$ hitung dalam penelitian ini sebesar 65,085dengan tingkat signifikansi uji $\mathrm{F}$ 0,000 $<0,05$ yang artinya model regresi layak untuk digunakan.Koefisien determinasi pada penelitian ini jika dilihat dari nilai Adjusted $R_{\text {square }}$ adalah sebesar 0,764. Ini berarti sebesar $76,4 \%$ variabel pengendalian intern dan kompetensi sumber daya manusia menjelaskan variasi dari kualitas laporan keuangan, sedangkan 23,6\% sisanya dijelaskan oleh variabel lain di luar model.

Nilai signifikansi uji $\mathrm{t}$ untuk variabel pengendalian intern pada kualitas laporan keuangan sebesar 0,000 lebih kecil dari $a=0,05$ dan nilai koefisien regresi sebesar 0,321. Hal ini menunjukkan bahwa pengendalian intern berpengaruh positif dan signifikan pada kualitas laporan keuangan, sehingga hipotesis pertama dalam penelitian ini diterima. Hal ini menunjukkan bahwa semakin tinggi pengawasan yang dilakukan dalam sistem pengendalian intern pada OPD kabupaten Badung, maka kualitas laporan keuangan yang dihasilkan akan semakin baik dan akurat.

Nilai signifikan uji t untuk variabel kompetensi sumber daya manusia pada kualitas laporan keuangan sebesar 0,633 lebih besar dari $a=0,05$ dan nilai koefisien regresi sebesar 0,034. Hal ini menunjukkan bahwa kompetensi sumber daya manusia tidak berpengaruh pada kualitas laporan keuangan, sehingga hipotesis kedua dalam penelitian ini ditolak.Hal ini berarti apabila terjadi peningkatan pada kompetensi SDM di kabupaten Badung maka tidak akan memberikan pengaruh pada kualitas laporan keuangan yang dihasilkan.

Nilai signifikansi uji $\mathrm{t}$ untuk variabel teknologi informasi memoderasi pengaruh pengendalian intern pada kualitas laporan keuangan sebesar 0,015 lebih kecil dari $a=0,05$ dan nilai koefisien regresi sebesar 0,274. Hal ini menunjukkan bahwa teknologi informasi mampu memperkuat pengaruh pengendalian intern pada kualitas laporan keuangan, sehingga hipotesis ketiga diterima. Hal ini berarti, adanya pemanfaatan teknologi informasi yang memadai di kabupaten Badung sangat bermanfaat untuk terciptanya efisiensi dan efektivitas di dalam penerapan pengendalian intern yang secara tidak langsung akan berdampak positif pada kualitas LKPD yang dihasilkan kabupaten Badung.

Nilai signifikansi uji $\mathrm{t}$ untuk variabel teknologi informasi memoderasi pengaruh kompetensi sumber daya manusia pada kualitas laporan keuangan sebesar 0,001 dari $a=0,05$ dan nilai koefisien regresi sebesar 0,386. Hal ini menunjukkan bahwa teknologi informasi memperkuat pengaruh kompetensi SDM pada kualitas laporan keuangan, sehingga hipotesis keempat diterima. Hal ini berarti pemanfaatan teknologi informasi di kabupaten Badung memberikan pengaruh pada hubungan kompetensi SDM pada kualitas laporan keuangan. Dalam melakukan pengelolaan keuangan, kabupaten Badung telah menggunakan teknologi informasi berupa aplikasi Sistem Informasi Manajemen Daerah (SIMDA).Pemanfaatan teknologi informasi berupa SIMDA membantu SDM di pusat pemerintahan kabupaten Badung dalam menyusun laporan keuangan sehingga dapat menghasilkan laporan keuangan yang berkualitas. 


\section{SIMPULAN}

Berdasarkan hasil analisis, simpulan penelitian ini adalah:Pengendalian intern berpengaruh positif signifikan pada kualitas laporan keuangan, kompetensi sumber daya manusia tidak berpengaruh pada kualitas laporan keuangan, teknologi informasi memperkuat pengaruh pengendalian intern dan kompetensi sumber daya manusia pada kualitas laporan keuangan

Dari hasil penelitian, pemerintah kabupaten Badung diharapkan dapat meningkatkan pemantauan dan pengawasan dalam penerapan pengendalian internagar tidak ada celah terjadinya penyimpangan maupun fraud. Pemerintah kabupaten Badung diharapkan untuk meningkatkan kompetensi sumber daya manusia secara rutin dengan mengadakan kegiatan pendidikan, pelatihan dan diklat-diklat yang berkaitan dengan penyusunan laporan keuangan guna meningkatkan kualitas laporan keuangan, dan memperhatikan penempatan sumber daya manusia yang masih belum disesuaikan dengan keahlian individual masing-masing, khususnya pada bagian akuntansi.Pemerintah kabupaten Badung juga diharapkan dapat meningkatkan dan memaksimalkan pemanfaatan teknologi informasi di lingkungan pemerintahan guna menunjang kompetensi sumber daya manusia dan penerapan pengendalian intern di kabupaten Badung serta dalam penyusunan laporan keuangan daerah.Peneliti selanjutnya dapat mengganti atau menambahkan variabel baru yang berkaitan dengan kualitas laporan keuangan seperti variabel motivasi kerja.

\section{REFERENSI}

Agung, T. M., \& . G. (2018). Analisis Faktor-Faktor yang Mempengaruhi Kualitas Laporan Keuangan Pemerintah Daerah Kabupaten Karangasem. EJurnal Akuntansi, 23, 1253. https://doi.org/10.24843/eja.2018.v23.i02.p17

Anwar, C., \& Mukadarul, D. M. (2016). The Influence Of Human Resources, Commitment Leader, The Use Of Information Technology, and System Internal Control On The Quality Of Local Government Financial Report Pringsewu. The Third International Conference on Law, Business, and Government Universitas Bandar Lampung.

Antara Bali. Sembilan Kabupaten/Kota di Bali raih WTP. https:/ / bali.antaranews.com/berita/128516/bpk-sembilan-kabupatenkota-di-bali-raih-wtp. Diakses pada Februari 2019

Badan Pengawasan Keuangan dan Pembangunan (2018). Laporan Hasil Pengawasan di Wilayah Provinsi Bali Tahun 2017. Melalui http://bpkp.go.id

Badan Pemeriksa Keuangan. (2018). Ikhtisar Hasil Pemeriksaan Semester I Tahun 2017. Melalui http:/ / www.bpk.go.id

Donaldson, L., \& Davis, J. H. (1991). Stewardship Theory or Agency Theory: CEO Governance and Shareholder Returns. Australian Journal Of Management, 16, 49-64. https:// doi.org/10.1177/031289629101600103

Ghozali, Imam. (2016). Aplikasi Analisis Multivariate dengan Program IBM SPSS 21 Up Date PLS Regresi. Edisi 8. Semarang: Badan Penerbit Universitas Diponegoro. 
Golshani, M. A., \& Jamshidinavid, B. (2017). The Effect of Auditing Quality on Financial Statements. International Journal of Economic Perspectives, 11(4), 451-457.

Hertati, L., Zarkasyih, W., Suharman, H., \& Umar, H. (2019). The Effect of Human Resource Ethics on Financial Reporting Implications for Good Government Governance (Survey of Related Sub-Units in State-Owned Enterprises in Sumsel). International Journal of Economics and Financial Issues, 9(4), 267-276. https:// doi.org/10.32479/ijefi.8466

Hidayah, N., \& Zarkasyi, W. (2017). The Effect of Human Resources Management Competency and the Role of Culture on Accrual Accounting Implementation Effectiveness and the Impact on Quality of Accounting Information. European Research Studies Journal, XX(4B), 183-199.

Ihsanti, E. (2014). Pengaruh Kompetensi Sumber Daya Manusia dan Penerapan Sistem Akuntansi Keuangan Daerah Terhadap Kualitas Laporan Keuangan Daerah (Studi Empiris Pada SKPD Kab. Lima Puluh Kota). EJurnal Akuntansi Universitas Negeri Padang.

Kardan, B., Salehi, M., \& Abdollahi, R. (2015). The relationship between the outside financing and the quality of financial reporting : evidence from Iran. Journal of Asia Business Studies, 10(1), 20-40. https:/ / doi.org/10.1108/JABS-04-2014-0027

Karmila, K., Tanjung, A. R., \& Darlis, E. (2014). Pengaruh Kapasitas Sumber Daya Manusia, Pemanfaatan Teknologi Informasi, Dan Pengendalian Intern Terhadap Keterandalan Pelaporan Keuangan Pemerintah Daerah (Studi Pada Pemerintah Provinsi Riau). Jurnal Sorot, 9(1), 25. https:// doi.org/10.31258/sorot.9.1.2331

Keay, A. (2016). Stewardship theory: is board accountability necessary? International Journal of Law and Management, 59(6), 1292-1314. https:// doi.org/10.1108/ijlma-11-2016-0118

Kewo, C. L., \& Afiah, N. N. (2017). Does Quality Of Financial Statement Affected By Internal Control System and Internal Audit? International Journal Of Economics and Financial Issues, 7(2), 568-573.

Kiranayanti, I. A. E., \& Erawati, N. M. A. (2016). Pengaruh Sumber Daya Manusia, Sistem Pengendalian Intern, Pemahaman Basis Akrual terhadap Kualitas Laporan Keuangan Daerah. E-Jurnal Akuntansi Universitas Udayana, 16(2), 1290-1318.

Le, T. T. H., \& Tran, M. D. (2018). The Effect of Internal Control On Asset Misappropriation: The Case of Vietnam. BEH-Business and Economic Horizons, 14(4), 941-953.

Mahaputra, i P. U. R., \& Putra, I. W. (2014). Analisis Faktor-Faktor Yang Memengaruhi Kualitas Informasi Pelaporan Keuangan Pemerintah Daerah. E-Jurnal Akuntansi Universitas Udayana, 8(2), 230-244.

Mutnuru, S. (2016). The Role of Internal Controls on Employees ' Engagement in Small Organizations. Journal of Business Studies Quarterly, 7(4).

Pemerintah Kabupaten Badung. (2018). Daftar Nama OPD yang Berbentuk Dinas dan Badan di Wilayah Kabupaten Badung. Melalui http://badungkab.go.id

Peraturan Pemerintah Nomor 56 Tahun 2005 Tentang Sistem Informasi Keuangan Daerah. 
Peraturan Pemerintah Nomor 60 Tahun 2006 Tentang Sistem Pengendalian Intern Pemerintah.

Peraturan Pemerintah Nomor 71 Tahun 2010 Tentang Standar Akuntansi Pemerintahan.

Peraturan Bupati Badung Nomor 78 Tahun 2016 Tentang Kedudukan, Susunan Organisasi, Tugas dn Fungsi, serta Tata Kerja Perangkat Daerah.

Ponamon, I. F. (2014). Pengaruh Pengawasan Internal, Pemahaman Sistem Akuntansi Keuangan, dan kapasitas Sumber Daya Manusia Terhadap Kualitas Informasi Laporan Keuangan Pemerintah Daerah Pada SKPD Pemerintah Kota Manado. Jurnal Riset Akuntansi Going Concern Universitas Sam Ratulangi, 9(2), 68-80.

Primayana, K. H., Atmadja, A. T., \& Darmawan, N. A. S. (2014). Pengaruh Kapasitas Sumber Daya Manusia, Pengendalian Intern Akuntansi, Pemanfaatan Teknologi Informasi, Dan Pengawasan Keuangan Daerah Terhadap Keterandalan Pelaporan Keuangan Pemerintah Daerah (Studi Pada Pemerintah Daerah Kabupaten Buleleng). E-Journal S1 Ak Universitas Pendidikan Ganesha, 2(1). Retrieved from http://ejournal.undiksha.ac.id/index.php/S1ak/article/view/2492

Rubino, M., Vitolla, F., \& Garzoni, A. (2017). The Impact of an IT Governance Framework on The Internal Control Environment. Records Management Journal, 27(1), 19-41. https:/ / doi.org/10.1108/RMJ-03-2016-0007

Safkaur, O., Afiah, N. N., Poulus, S., \& Dahlan, M. (2019). The Effect of Quality Financial Reporting on Good Governance. International Journal of Economics and Financial Issues, 9(3), 277-286. https:// doi.org/10.32479/ijefi.8047

Sagara, Y. (2015). The Effect of Implementation Accounting Information System and Competence of Human Resources on the Quality of Financial Reporting. Research Journal Of Finance and Accounting, 6(10), 111-116.

Sari, N. (2016). Pengaruh Kapasitas Sumber Daya Manusia, Pemahaman Akuntansi, Penerapan SAP, Pemanfaatan Teknologi Informasi, dan Sistem Pengendalian Intern Terhadap Kualitas Laporan Keuangan Pemerintah Daerah (Studi Empiris Pada Satuan Kerja Perangkat Daerah Kabuapten Bu. Jurnal Online Mahasiswa Fakultas Ekonomi UNRI, 3(1), 1478-1490.

Septarini, D. F., \& Papilaya, F. (2016). Interaksi Komitmen Organisasi Terhadap Faktor-Faktor Yang Memengaruhi Kualitas Laporan Keuangan Pemerintah Daerah. Jurnal Ilmu Ekonomi \& Sosial, VII(2), 100-116.

Setiawan, I. W. N., \& Gayatri. (2017). Pengaruh Akuntansi Berbasis Akrual, Sistem Pengendalian Intern dan Motivasi Kerja Pada Kualitas Laporan Keuangan Fakultas Ekonomi dan Bisnis Universitas Udayana ( Unud ), Bali, Indonesia Fakultas Ekonomi dan Bisnis. E-Journal Akuntansi Universitas Udayana, 21(1), 671-700.

Siwambudi, I. G. N., Yasa, G. W., \& Badera, I. D. N. (2017). Komitmen Organisasi Sebagai Pemoderasi Pengaruh Kompetensi SDM dan Sistem Pengendalian Intern Pada Kualitas Laporan keuangan. E-Jurnal Ekonomi Dan Bisnis Universitas Udayana, 6(1), 385-416. 
Suarmika, I. G. L., Gede, I. D., \& Suputra, D. (2016). Kemampuan Komitmen Organisasi dan Sistem Pengendalian Intern Memoderasi Pengaruh kapasitas SDM dan Penerapan SIKD Pada Kualitas LKPD kabupaten Karangasem. E-Jurnal Ekonomi Dan Bisnis Universitas Udayana, 5(9), 29212950.

Sugandi, J., Desmiyawati, \& Hanif, R. A. (2014). Pengaruh Kapasitas Sumber Daya manusia, Pemanfaatan Teknologi Informasi, Pengendalian Intern Akuntansi, dan Komitmen Organisasi Terhadap Keterandalan Pelaporan Keuangan Pemerintah daerah (Survei Pada SKPD SeKabupaten Kuansing. Jurnal Online Mahasiswa (JOM) Bidang Imu Ekonomi Universitas Riau, 1(1).

Sugiyono. (2017). Metode Penelitian Bisnis. In Bandung: Alfabeta.

Suwanda, D. (2015). Factors Affecting Quality of Local Government Financial Statements to Get Unqualified Opinion ( WTP ) of Audit Board of the Republic of Indonesia ( BPK ). Research Journal Of Finance and Accounting, 6(4), 139-158.

Tambingon, H. N., Yadiati, W., \& Kewo, C. L. (2018). Determinant Factors Influencing the Quality of Financial Reporting Local Government in Indonesia. International Journal Of Economics and Financial Issues, 8(2), 262-268.

Trisnawati, N. N., \& Wiratmaja, D. N. (2018). Pengaruh Kualitas Sumber Daya Manusia dan Sistem Pengendalian Intern pada Kualitas Laporan Keuangan Pemerintah Daerah. E-Jurnal Akuntansi, 24, 768. https:// doi.org/10.24843/eja.2018.v24.i01.p29

Urbanik, V. (2016). Making Internal Control a Priority in Local Government. Journal of Government Financial Management, 20-25.

Utama, R. J. (2017). Pengaruh Kompetensi Sumber daya Manusia, Pemanfaatan Teknologi Informasi, Penerapan Sistem Akuntansi Keuangan Daerah dan Sistem Pengendalian Intern Terhadap Kualitas Laporan Keuangan Pemerintah Daerah (Studi Pada Satuan Kerja Perangkat Daerah Kabupaten In. JOM Fekom, 4(1), 1429-1443.

Wati, K. D., Herawati, N. T., \& Sinarwati, N. K. (2014). Pengaruh Kompetensi SDM, Penerapan SAP, dan Sistem Akuntansi Keuangan daerah Terhadap Kualitas Laporan Keuangan Daerah. E-Journal S1 AK Universitas Pendidikan Ganesha, 2(1). 